\title{
OPEN Highly efficient removal of thallium(I) by facilely fabricated amorphous titanium dioxide from water and wastewater
}

\author{
Gaosheng Zhang ${ }^{1 凶}$, Jinglin $\mathrm{Luo}^{1,3}$, Hanlin $\mathrm{CaO}^{4}$, Shengping $\mathrm{Hu}^{1}$, Huosheng $\mathrm{Li}^{1}$, Zhijing Wu${ }^{1}$, \\ Yuan $\mathrm{Xie}^{5}$ \& Xiangping $\mathrm{Li}^{2 \bowtie}$
}

In this study, amorphous hydrous titanium dioxide was synthesized by a facile precipitation method at room temperature, aiming to effectively remove thallium(I) from water. The titanium dioxide prepared using ammonia as precipitant $\left(\mathrm{TiO}_{2}{ }^{\prime}\right)$ is more effective for thallium(I) uptake than the one synthesized with sodium hydroxide $\left(\mathrm{TiO}_{2}{ }^{\prime \prime}\right)$. The $\mathrm{TiO}_{2}$ obtained particles are amorphous, aggregates of many nanoparticles and irregular in shape. The thallium(I) uptake increases with the rise of solution $\mathrm{pH}$ value. Under neutral $\mathrm{pH}$ conditions, the maximal thallium(I) adsorption capacities of $\mathrm{TiO}_{2}{ }^{\prime}$ and $\mathrm{TiO}_{2}{ }^{\prime \prime}$ are 302.6 and $230.3 \mathrm{mg} / \mathrm{g}$, respectively, outperforming most of the reported adsorbents. The amorphous $\mathrm{TiO}_{2}$ has high selectivity towards thallium(I) in the presence of multiple cations such as $\mathrm{K}^{+}, \mathrm{Ca}^{2+}, \mathrm{Mg}^{2+}, \mathrm{Zn}^{2+}$ and $\mathrm{Ni}^{2+}$. Moreover, the $\mathrm{TiO}_{2}{ }^{1}$ is efficient in removing thallium(I) from real river water and mining wastewater. Additionally, the spent $\mathrm{TiO}_{2}{ }^{\prime}$ can be regenerated using hydrochloric acid solution and reused. The $\mathrm{TI}(\mathrm{I})$ adsorption is achieved via replacing the $\mathrm{H}^{+}$in hydroxyl group on the surface of $\mathrm{TiO}_{2}$ and forming inner-sphere surface complexes. Owing to its high efficiency, facile synthesis and environmental friendliness, the $\mathrm{TiO}_{2}{ }^{\prime}$ has the potential to be used as an alternative adsorbent to remove $\mathrm{TI}(\mathrm{I})$ from water.

As a non-essential heavy metal to living organisms, thallium (Tl) has attracted more and more attentions because of its high toxicity ${ }^{1-4}$. Thallium occurs at very low levels in the natural aquatic environment ${ }^{1,2}$. However, anthropogenic activities such as coal combustion, mining and processing of Tl-hosting minerals lead to the release of large amount of $\mathrm{Tl}$ into natural water bodies, which pose a great threat to aquatic biota and human health ${ }^{2}$. To abate the health risk associated with exposure to thallium through drinking, stringent criteria for Tl concentration in water/wastewater have been established in many countries. For instance, in the United States, the USEPA has set 2 and $140 \mu \mathrm{g} / \mathrm{L}$ as the maximum $\mathrm{Tl}$ level in drinking water and wastewater discharged, respectively; in China, the limit of Tl in drinking water has been lowered to $0.1 \mu \mathrm{g} / \mathrm{L}$ and more stringent standard of $2 \mu \mathrm{g} / \mathrm{L}$ has been adopted as the discharge standard for industrial wastewater in some provinces ${ }^{3,4}$.

In aquatic environment, thallium usually exists in two oxidation states: thallous (I) and thallic (III) ${ }^{3}$. Tl(I) is considered to be very mobile and thus difficult to remove, because it generally forms most stable compounds in natural waters ${ }^{1,5}$. Therefore, in the thallium treatment domain most of the researches concerned $\mathrm{Tl}(\mathrm{I})$ removal. A variety of techniques including adsorption ${ }^{6,7}$, oxidation/precipitation ${ }^{8-10}$, ion exchange ${ }^{11,12}$, solvent extraction ${ }^{13,14}$, etc., have been used to treat Tl-containing water and wastewater. In comparation with other methods, adsorption has recently gained more and more attentions, due to the advantages of high efficiency, affordable cost, simple operation and little toxic sludge generation ${ }^{3,6}$. Numerous adsorbents such as carbon materials ${ }^{15,16}$, mineral materials $s^{17,18}$, biomass materials ${ }^{19}$, Prussian blue and analogues ${ }^{20-22}$, manganese oxides ${ }^{23-27}$ and titanium-based materials ${ }^{28-30}$, have been employed to remove $\mathrm{Tl}(\mathrm{I})$ from water or wastewater.

\footnotetext{
${ }^{1}$ Key Laboratory for Water Quality and Conservation of the Pearl River Delta, School of Environmental Science and Engineering, Ministry of Education, Guangzhou University, Guangzhou 510006, China. ${ }^{2}$ School of Chemistry and Chemical Engineering, Guangzhou University, Guangzhou 510006, China. ${ }^{3}$ Guangzhou Huake Environmental Protection Engineering Co., Ltd., Guangzhou 510655, China. ${ }^{4}$ Technical Centre for Soil, Agriculture and Rural Ecology and Environment, Ministry of Ecology and Environment, Beijing 100012, China. ${ }^{5}$ Guangdong Provincial Key Laboratory of Radioactive and Rare Resource Utilization, Shaoguan 512026, China. ${ }^{\varpi}$ email: gszhang@ gzhu.edu.cn; lxping@gzhu.edu.cn
} 
Titanium dioxide has been extensively investigated and used to remove heavy metal contaminants such as $\mathrm{Cs}(\mathrm{I}), \mathrm{Cu}(\mathrm{II}), \mathrm{Pb}(\mathrm{II}), \mathrm{Cd}(\mathrm{II}), \mathrm{Ni}(\mathrm{II}), \mathrm{As}(\mathrm{III}), \mathrm{As}(\mathrm{V}), \mathrm{Cr}(\mathrm{III}), \mathrm{Cr}(\mathrm{VI}), \mathrm{U}(\mathrm{VI})$ and $\mathrm{Th}(\mathrm{IV})$ from water or wastewater ${ }^{31-35}$, owing to its nontoxicity, affordable cost, good chemical stability and high affinity for these ions. However, little work has been done on the removal of $\mathrm{Tl}(\mathrm{I})$ with titanium dioxide. For instance, $\mathrm{Tl}(\mathrm{I})$ adsorption on anatase $\mathrm{TiO}_{2}$ (Degussa, P25) was studied by Kajitvichyanukul et al. and the maximal adsorption capacity was found to be only $6.3 \mathrm{mg} / \mathrm{g}$ under neutral $\mathrm{pH}$ conditions $^{36}$; Asadpour et al. investigated the $\mathrm{Tl}(\mathrm{I})$ adsorption on anatase $\mathrm{TiO}_{2}$ nanoparticles synthesized via ultrasound method and found that its maximal adsorption capacity was $25 \mathrm{mg} / \mathrm{g}$ at $\mathrm{pH} 9.0^{37}$; Zhang et al. evaluated the $\mathrm{Tl}(\mathrm{I})$ adsorption on commercial rutile nano- $\mathrm{TiO}_{2}$ and determined that the maximum adsorption capacity was $51.2 \mathrm{mg} / \mathrm{g}$ at $\mathrm{pH} 7.0 \pm 0.3^{38}$. Evidently, these well-crystalline $\mathrm{TiO}_{2}$ nanoparticles have relatively low $\mathrm{Tl}(\mathrm{I})$ adsorption capacity and are not feasible for $\mathrm{Tl}(\mathrm{I})$ removal. Therefore, it is vital and challenging to synthesize titanium dioxide with high-efficiency adsorption of $\mathrm{Tl}(\mathrm{I})$. The amorphous $\mathrm{TiO}_{2}$ may be a feasible choice because it often possesses abundant active sites, which are responsible for $\mathrm{Tl}(\mathrm{I})$ adsorption. Recently, a poor crystalline $\mathrm{TiO}_{2}$ had been prepared by a simple precipitation method in our laboratory. The as-synthesized $\mathrm{TiO}_{2}$ demonstrated a high maximal $\mathrm{Tl}(\mathrm{I})$ adsorption capacity of $239 \mathrm{mg} / \mathrm{g}$ at $\mathrm{pH}$ $7.0 \pm 0.1^{29}$, which was remarkably superior to the well-crystalline $\mathrm{TiO}_{2}$. In addition, it could be easily synthesized in large scale. This is very interesting and the amorphous $\mathrm{TiO}_{2}$ might be a potential sorbent for effective $\mathrm{Tl}(\mathrm{I})$ removal because of its high performance, good chemical stability, cost-effectiveness, facile synthesis and environmental friendliness. However, to our best knowledge, the influence of precipitant used to prepare amorphous $\mathrm{TiO}_{2}$ on $\mathrm{Tl}(\mathrm{I})$ adsorption has never been investigated. Additionally, adsorption behavior and mechanism of $\mathrm{Tl}(\mathrm{I})$ on the amorphous $\mathrm{TiO}_{2}$ have never been systemically studied.

Hence, in this study, two different precipitants $\left(\mathrm{NH}_{3} \cdot \mathrm{H}_{2} \mathrm{O}\right.$ and $\left.\mathrm{NaOH}\right)$ were used to synthesize the amorphous $\mathrm{TiO}_{2}$ via a facile precipitation method at room temperature. The synthesized $\mathrm{TiO}_{2}$ was characterized with a variety of techniques. The adsorption behaviors such as kinetics, isotherm, solution $\mathrm{pH}$ effect and coexisting cation influence were studied in details. Additionally, removal of thallium(I) from mining wastewater and natural river water was also evaluated. Moreover, a possible removal mechanism of thallium(I) was proposed.

\section{Materials and methods}

Materials. All chemicals such as $\mathrm{Ti}\left(\mathrm{SO}_{4}\right)_{2}, \mathrm{NH}_{3} \cdot \mathrm{H}_{2} \mathrm{O}(30 \%), \mathrm{NaOH}, \mathrm{NaNO}_{3}, \mathrm{TlNO}_{3}$ and nano-TiO $(\mathrm{P} 25)$ were purchased from Sinopharm Chemical Reagent Co. Ltd (Shanghai, China) and were analytical grade and used without further purification. $\mathrm{Tl}(\mathrm{I})$ stock solution was prepared by dissolving $\mathrm{TlNO}_{3}$ in deionized water. Prior to use, the working solution was freshly prepared by diluting $\mathrm{Tl}(\mathrm{I})$ stock solution to specified concentration with deionized water.

Preparation of titanium dioxide. Titanium dioxide was prepared by a simple chemical precipitation method at room temperature. Briefly, $7.2 \mathrm{~g} \mathrm{Ti}\left(\mathrm{SO}_{4}\right)_{2}$ was dissolved in a $200 \mathrm{~mL}$ deionized water. Under vigorously stirring, $10 \%$ ammonia solution or $1 \mathrm{M} \mathrm{NaOH}$ solution was then dropwise added to the $\mathrm{Ti}\left(\mathrm{SO}_{4}\right)_{2}$ solution until the $\mathrm{pH}$ was raised to approximately 7.5. The white precipitates produced were washed for several times using deionized water, then filtrated and dried at $55^{\circ} \mathrm{C}$ for $24 \mathrm{~h}$. The obtained titanium dioxides were denoted as $\mathrm{TiO}_{2}{ }^{\mathrm{I}}$ (using $\mathrm{NH}_{3} \cdot \mathrm{H}_{2} \mathrm{O}$ as precipitant) and $\mathrm{TiO}_{2}{ }^{\mathrm{II}}$ (using $\mathrm{NaOH}$ as precipitant), respectively. In addition, titanium dioxide was also prepared by forced hydrolysis of $\mathrm{Ti}\left(\mathrm{SO}_{4}\right)_{2}$ at $70{ }^{\circ} \mathrm{C}$ for $4 \mathrm{~h}$, and the as-prepared sample was denoted as $\mathrm{TiO}_{2}{ }^{\mathrm{III}}$.

Characterization. X-ray diffraction (XRD) analysis was performed on a PW3040/60 diffractometer (Philips Co., the Netherlands). The morphology of the synthesized and commercial $\mathrm{TiO}_{2}$ was observed with a Sigma 500 field scanning electron microscope (FESEM) (Carl Zeiss, Germany) and transmission electron microscope (TEM) (JEM-1230, JEOL, Japan). X-ray photoelectron spectra (XPS) were collected on an AXIS Supra spectrometer (Shimadzu Co., Japan) with a monochromatic Al Ka X-ray source (1486.6 eV). The XPS results were collected in binding energy forms and fitted using a nonlinear least-squares curve-fitting program (XPSPEAK41 Software).

$\mathrm{TI}(\mathrm{I})$ adsorption experiments. Batch tests were performed to estimate $\mathrm{Tl}(\mathrm{I})$ removal by the synthesized and commercial $\mathrm{TiO}_{2}$. Briefly, $10 \mathrm{mg} \mathrm{TiO}$ was added into $100 \mathrm{~mL}$ polyethylene bottles, which contain $50 \mathrm{~mL}$ $\mathrm{Tl}(\mathrm{I})$ solution with different concentrations. The solution $\mathrm{pH}$ was adjusted with $0.1 \mathrm{M} \mathrm{NaOH}$ and/or $\mathrm{HNO}_{3}$. The bottles were then sealed and were shaken on an orbital oscillator at $180 \mathrm{rpm}$ for $24 \mathrm{~h}$. Afterwards, supernatant was collected and filtered through a $0.45 \mu \mathrm{m}$ membrane. More detailed description of adsorption tests is shown in the Supplementary Material.

$\mathrm{TI}(\mathrm{I})$ removal from real surface water and wastewater. To estimate the practicability of the synthesized $\mathrm{TiO}_{2}$, $\mathrm{Tl}(\mathrm{I})$ removal from real wastewater and spiked surface water was studied by batch experiments. The surface water was collected from the Pearl River near to Guangzhou University, China and the mining wastewater was sampled from a mining area, Guizhou Province, China. The river water $\mathrm{pH}$ value was 7.56 and spiked $\mathrm{Tl}(\mathrm{I})$ concentration was $20 \mu \mathrm{g} / \mathrm{L}$. More detailed parameters of water quality were listed in Table S1. The $\mathrm{pH}$ value of mining wastewater was 2.73 and $\mathrm{Tl}$ concentration was $4.9 \mu \mathrm{g} / \mathrm{L}$. More detailed parameters of water quality were summarized in Table S2. For the spiked river water, defined amount of $\mathrm{TiO}_{2}{ }^{\mathrm{I}}$ (10 or 20 or $40 \mathrm{mg}$ ) was added into a $2000-\mathrm{mL}$ beaker containing $1000 \mathrm{~mL}$ spiked Pearl River water. Afterwards, the solution was agitated by a magnetic stirrer at a speed of $200 \mathrm{rpm} .5 \mathrm{~mL}$ water sample was taken from the beaker at predetermined times. The samples were then filtered using a filter with $0.45-\mu \mathrm{m}$ membrane. The residual $\mathrm{Tl}$ concentration was meas- 


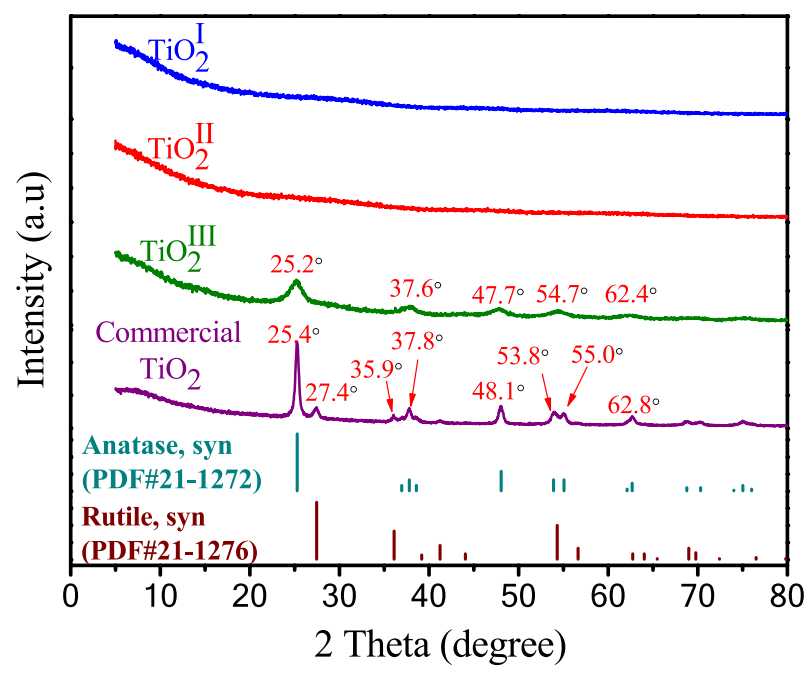

Figure 1. XRD patterns of synthesized and commercial $\mathrm{TiO}_{2}$.

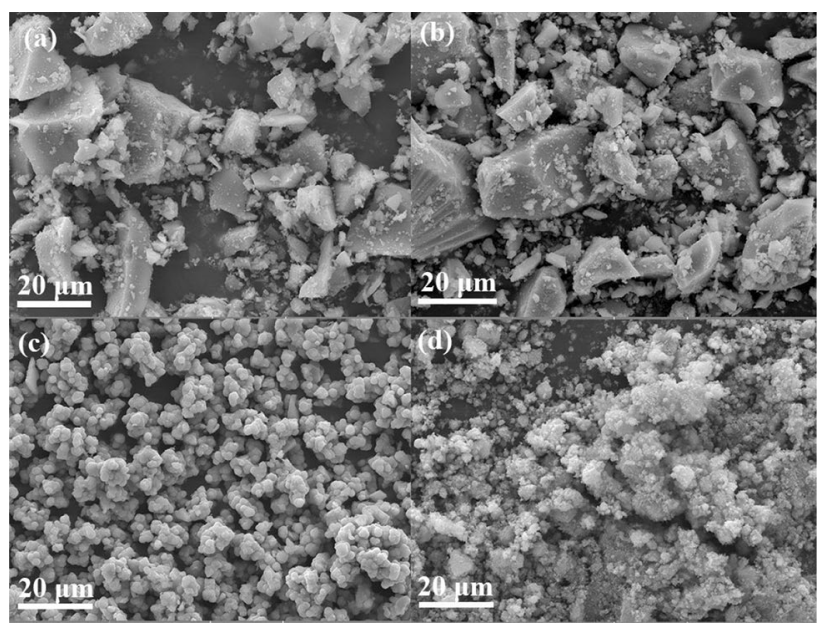

Figure 2. SEM images of $\mathrm{TiO}_{2}{ }^{\mathrm{I}}(\mathbf{a}), \mathrm{TiO}_{2}{ }^{\mathrm{II}}(\mathbf{b}), \mathrm{TiO}_{2}{ }^{\mathrm{III}}$ (c) and commercial $\mathrm{TiO}_{2}(\mathbf{d})$.

ured by an inductively coupled plasma mass spectrometry (ICP-MS). For mining wastewater, the test procedure was similar to the spiked river water.

Analytical methods. Before analysis, the aqueous samples collected were acidified with $\mathrm{HNO}_{3}$ solution, and stored in glass bottles. $\mathrm{Tl}(\mathrm{I})$ concentration was determined by inductively coupled plasma mass spectrometry (ICP-OES, Avio 200, Perkin Elmer Co. USA). Trace level Tl was determined using an inductively coupled plasma mass spectrometry machine (ICP-MS, NexION 300, Perkin Elmer Co. USA).

\section{Results and discussion}

Characterization of $\mathrm{TiO}_{2}$. Figure 1 shows the X-ray diffraction patterns of synthesized and commercial titanium dioxides. For $\mathrm{TiO}_{2}{ }^{\mathrm{I}}$ and $\mathrm{TiO}_{2}{ }^{\mathrm{II}}$, no obvious diffraction peaks can be observed, indicating that both of them are amorphous. Wang et al. had also synthesized amorphous $\mathrm{TiO}_{2}$ and observed similar phenomenon ${ }^{39}$. For $\mathrm{TiO}_{2}{ }^{\mathrm{III}}$, five weak peaks appear at approximately $25.2,37.6,47.7,54.7$ and $62.4^{\circ}$, respectively, which are corresponding to the characteristic diffraction peaks of anatase (PDF\#21-1272). This suggests that the anatase $\mathrm{TiO}_{2}{ }^{\mathrm{III}}$ is not well-crystalline. For commercial $\mathrm{TiO}_{2}$, several strong peaks appear at $25.4^{\circ}, 27.4^{\circ}, 35.9^{\circ}, 37.8^{\circ}, 48.1^{\circ}, 53.8^{\circ}$, $55.0^{\circ}$ and $62.8^{\circ}$, respectively. The peaks at $25.4^{\circ}, 37.8^{\circ}, 48.1^{\circ}, 53.8^{\circ}, 55.0^{\circ}$ and $62.8^{\circ}$ coincide with those of anatase and peaks at 27.4 and $35.9^{\circ}$ are in agreement with those of rutile, implying that the commercial $\mathrm{TiO}_{2}$ contains both well-crystalline anatase and rutile phase. Figure 2 exhibits the SEM images of the synthesized and commercial titanium dioxides. As can be seen, both $\mathrm{TiO}_{2}{ }^{\mathrm{I}}$ and $\mathrm{TiO}_{2}{ }^{\mathrm{II}}$ are irregular in shape and constituted by many small particles, while the $\mathrm{TiO}_{2}{ }^{\mathrm{III}}$ demonstrates a regular sphere-like shape with a particle size of $1-3 \mu \mathrm{m}$. The commercial $\mathrm{TiO}_{2}$ particles are aggregates of smaller nanoparticles. TEM images of these four materials are demonstrated in Fig. 3. The TEM images of $\mathrm{TiO}_{2}{ }^{\mathrm{I}}$ and $\mathrm{TiO}_{2}{ }^{\mathrm{II}}$ further confirm that they are agglomerates of nanoparticles and 


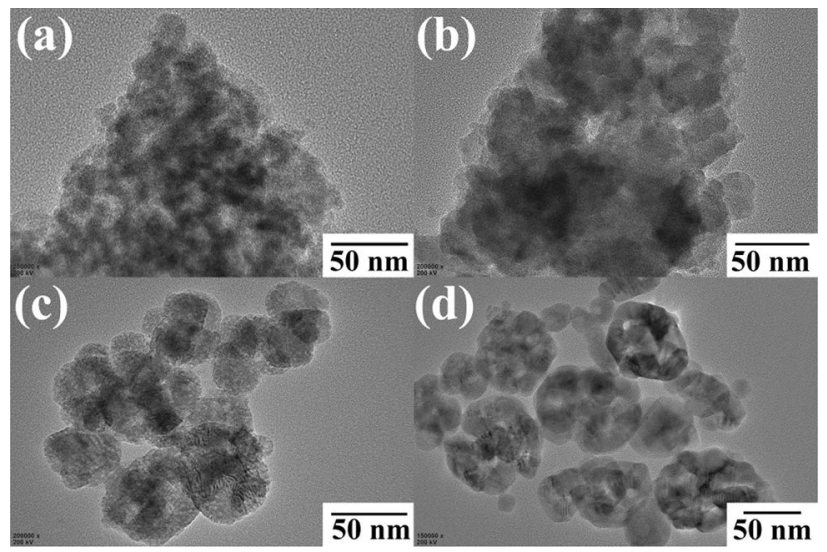

Figure 3. TEM images of $\mathrm{TiO}_{2}{ }^{\mathrm{I}}(\mathbf{a}), \mathrm{TiO}_{2}{ }^{\mathrm{II}}(\mathbf{b}), \mathrm{TiO}_{2}{ }^{\mathrm{III}}$ (c) and commercial $\mathrm{TiO}_{2}(\mathbf{d})$.

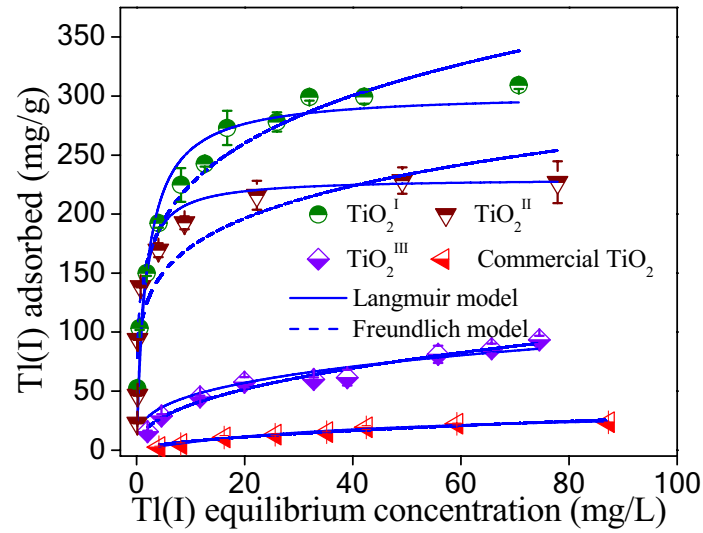

Figure 4. Adsorption isotherms of $\mathrm{Tl}(\mathrm{I})$ on the synthesized and commercial $\mathrm{TiO}_{2}$. Experiment conditions: Adsorbent dosage $=0.2 \mathrm{~g} / \mathrm{L} ; \mathrm{pH}=7.0 \pm 0.1$ and $\mathrm{T}=25 \pm 1{ }^{\circ} \mathrm{C}$.

amorphous. Relatively, the $\mathrm{TiO}_{2}{ }^{\mathrm{III}}$ displays a polyhedron shape with certain crystallinity. The commercial $\mathrm{TiO}_{2}$ presents well-crystalline nanoparticles with particle size of about 15-30 nm.

Adsorption isotherms. To evaluate the Tl(I) adsorption capacities of the synthesized and commercial titanium dioxides, the adsorption isotherm experiments were conducted at neutral circumstance. The results are illustrated in Fig. 4. Clearly, the adsorption capacities of synthesized titanium dioxides are far higher than that of the commercial one. Furthermore, the $\mathrm{TiO}_{2}$ synthesized via chemical precipitation has much higher adsorption capacity than the one prepared by forced hydrolysis. The differences in the maximum adsorption capacity between them might be ascribed to their crystallinity. The amorphous $\mathrm{TiO}_{2}$ may have more surface hydroxyl groups than well-crystalline $\mathrm{TiO}_{2}$, which are responsible for the $\mathrm{Tl}(\mathrm{I})$ adsorption. Interestingly, both $\mathrm{TiO}_{2}{ }^{\mathrm{I}}$ and $\mathrm{TiO}_{2}{ }^{\mathrm{II}}$ are rather efficient for $\mathrm{Tl}(\mathrm{I})$ removal, particularly for low concentration of $\mathrm{Tl}(\mathrm{I})$. In addition, it can be seen that the precipitant used to synthesize amorphous $\mathrm{TiO}_{2}$ has great effect on $\mathrm{Tl}(\mathrm{I})$ adsorption. $\mathrm{The}^{\mathrm{TiO}} \mathrm{O}_{2}$ obtained using $\mathrm{NH}_{3} \cdot \mathrm{H}_{2} \mathrm{O}$ as precipitant is much more effective for $\mathrm{Tl}(\mathrm{I})$ adsorption. However, extensive use of $\mathrm{NH}_{3} \cdot \mathrm{H}_{2} \mathrm{O}$ might lead to ammonia pollution. The experimental data were fitted by the Langmuir model (Eq. (S1)) and Freundlich model (Eq. (S2)). The fitting curves are demonstrated in Fig. 4 and the adsorption constants obtained from the isotherms are listed in Table 2. It can be observed that the Langmuir model is more suitable for describing the adsorption behavior, due to the higher regression coefficients (Table 1). This indicates that the $\mathrm{Tl}(\mathrm{I})$ adsorption on the $\mathrm{TiO}_{2}$ follows a monolayer adsorption process, since the Langmuir model assumes that adsorption is limited to one monolayer. The maximal adsorption capacities of $\mathrm{TiO}_{2}{ }^{\mathrm{I}}, \mathrm{TiO}_{2}{ }^{\mathrm{II}}, \mathrm{TiO}_{2}{ }^{\mathrm{III}}$ and commercial $\mathrm{TiO}_{2}$ are 302.6, 230.3, 106.3 and $34.7 \mathrm{mg} / \mathrm{g}$ at $\mathrm{pH}$ 7.0, respectively. A comparison between the synthesized $\mathrm{TiO}_{2}$ and adsorbents reported in literature for $\mathrm{Tl}(\mathrm{I})$ adsorption has been done (Table 2). Evidently, both $\mathrm{TiO}_{2}{ }^{\mathrm{I}}$ and $\mathrm{TiO}_{2}{ }^{\mathrm{II}}$ are more competitive than the majority of reported adsorbents, implying that amorphous $\mathrm{TiO}_{2}$ is a promising alternative for $\mathrm{Tl}(\mathrm{I})$ removal from water. Therefore, investigation was focused on the $\mathrm{TiO}_{2}{ }^{\mathrm{I}}$ and $\mathrm{TiO}_{2}{ }^{\mathrm{II}}$ in the following sections.

$\mathrm{TI}(\mathrm{I})$ adsorption kinetics. Figure 5 presents the adsorption kinetics data of $\mathrm{Tl}(\mathrm{I})$ on the $\mathrm{TiO}_{2}{ }^{\mathrm{I}}$ and $\mathrm{TiO}_{2}{ }^{\mathrm{II}}$. A fast adsorption of $\mathrm{Tl}(\mathrm{I})$ was observed within the first $0.5 \mathrm{~h}$. During this period, about 87.3 and $81.1 \%$ of equilib- 


\begin{tabular}{|c|c|c|c|c|c|c|}
\hline \multirow[b]{2}{*}{ Adsorbent } & \multicolumn{3}{|c|}{ Langmuir model } & \multicolumn{3}{|c|}{ Freundlich model } \\
\hline & $q_{\max }\left(\mathrm{mg} \mathrm{g}^{-1}\right)$ & $k_{\mathrm{L}}\left(\mathrm{L} \mathrm{mg}^{-1}\right)$ & $R^{2}$ & $k_{\mathrm{F}}\left(\mathrm{L} \mathrm{g}^{-1}\right)$ & $1 / n$ & $R^{2}$ \\
\hline $\mathrm{TiO}_{2}^{\mathrm{I}}$ & 302.6 & 0.528 & 0.951 & 139.7 & 0.208 & 0.949 \\
\hline $\mathrm{TiO}_{2}{ }^{\mathrm{II}}$ & 230.3 & 0.989 & 0.896 & 111.6 & 0.188 & 0.845 \\
\hline $\mathrm{TiO}_{2}{ }^{\mathrm{III}}$ & 104.3 & 0.059 & 0.933 & 22.4 & 0.312 & 0.921 \\
\hline Commercial $\mathrm{TiO}_{2}$ & 36.7 & 0.023 & 0.984 & 2.0 & 0.569 & 0.944 \\
\hline
\end{tabular}

Table 1. Langmuir and Freundlich isotherms parameters for $\mathrm{Tl}(\mathrm{I})$ adsorption on the synthesized and commercial titanium dioxides at $\mathrm{pH} 7.0 \pm 0.1$.

\begin{tabular}{|c|c|c|c|c|c|}
\hline Adsorbent & Tl equil. con. range $(\mathrm{mg} / \mathrm{L})$ & Dosage $(g / L)$ & $\mathrm{pH}$ & Max. sorption capacity (mg/g) & References \\
\hline $\mathrm{TiO}_{2}$ (Degussa, P25) & $0-160$ & 2.0 & 7.0 & 6.3 & 36 \\
\hline $\mathrm{TiO}_{2}$ nanoparticles & $0-30$ & 0.67 & 9.0 & 25 & 37 \\
\hline Nano- $\mathrm{TiO}_{2}$ & $0-12$ & - & 7.0 & 51.2 & 38 \\
\hline TNTs & $0-55$ & 0.2 & 5.0 & 709.2 & 28 \\
\hline TNM-30 & $0-550$ & 0.25 & 8.0 & 710.4 & 30 \\
\hline Titanium peroxide & $0-70$ & 0.2 & 7.0 & 412 & 29 \\
\hline $\mathrm{MnO}_{2}$ & $0-102$ & 0.5 & 5.0 & 349 & 23 \\
\hline FeOOH-loaded $\mathrm{MnO}_{2}$ & $0-140$ & 0.4 & 7.0 & 450 & 40 \\
\hline Fe-Mn binary oxide & $0-400$ & 0.5 & 10.0 & 236.4 & 41 \\
\hline $\mathrm{MnO}_{2} @$ pyrite cinder & $0-40$ & 0.5 & 12.0 & 320.1 & 42 \\
\hline Alginate-PB & $0-400$ & 1.0 & 4.0 & 103 & 22 \\
\hline MFBC & $0-300$ & 1.0 & 6.0 & 170 & 7 \\
\hline TFNPs & $0-50$ & 0.1 & 7.0 & 111.3 & 43 \\
\hline Biochar & $0-300$ & 2.0 & 6.5 & 178.4 & 44 \\
\hline $\mathrm{ZnKFeCN} @ \mathrm{Fe}_{3} \mathrm{O}_{4}$ composite & $0-160$ & 0.6 & 7.0 & 120 & 45 \\
\hline Commercial $\mathrm{TiO}_{2}$ & $0-80$ & 0.2 & 7.0 & 36.7 & Present study \\
\hline $\mathrm{TiO}_{2}^{\mathrm{III}}$ & $0-80$ & 0.2 & 7.0 & 104.3 & Present study \\
\hline $\mathrm{TiO}_{2}{ }^{\mathrm{II}}$ & $0-80$ & 0.2 & 7.0 & 230.3 & Present study \\
\hline $\mathrm{TiO}_{2}^{\mathrm{I}}$ & $0-80$ & 0.2 & 7.0 & 302.6 & Present study \\
\hline
\end{tabular}

Table 2. Comparison of $\mathrm{Tl}(\mathrm{I})$ maximal sorption capacities for different adsorbents.

rium $\mathrm{Tl}(\mathrm{I})$ adsorption capacity was achieved for $\mathrm{TiO}_{2}{ }^{\mathrm{I}}$ and $\mathrm{TiO}_{2}{ }^{\mathrm{II}}$, respectively. Afterwards, the $\mathrm{Tl}(\mathrm{I})$ adsorption rate became slower and the equilibrium was established within about $4 \mathrm{~h}$. Both the pseudo-first-order model (Eq. (S3)) and pseudo-second-order model (Eq. (S4)) were initially applied to stimulate the kinetic data. The fitting curves are depicted in Fig. 5 and constants obtained from these two models are provided in Table 3. In terms of $R^{2}$, it has been found that the pseudo-second order model fits better the kinetic data than the pseudo-first order model, indicating that removal process of $\mathrm{Tl}(\mathrm{I})$ by the synthesized $\mathrm{TiO}_{2}$ involves chemisorption.

Adsorption process is complicated and multi-step, involving bulk diffusion (adsorbate transport from the bulk solution to the outer surface of the liquid film), film diffusion (from the outer surface of the liquid film to the surface of the solid adsorbent), intraparticle diffusion (from the surface of the adsorbent to the interior pores), and adsorption on the surface actives of solid adsorbent ${ }^{46,47}$. The pseudo-second order model is therefore limited in accuracy because it considers adsorption as a single, one-step binding process ${ }^{48}$. Thus, intraparticle diffusion model (Eq. (S5)) was further used to describe the experimental data. The fitting results are shown in Fig. S1. For both $\mathrm{TiO}_{2}{ }^{\mathrm{I}}$ and $\mathrm{TiO}_{2}{ }^{\mathrm{II}}$, the plot of $q_{\mathrm{t}}$ vs $t^{1 / 2}$ can be divided into two linear segments, indicating that $\mathrm{Tl}(\mathrm{I})$ adsorption contains multiple steps. The first linear section is corresponding to the fast adsorption stage, which is mainly controlled by film diffusion. The second linear section is a slow stage, which is governed by the diffusion of $\mathrm{Tl}(\mathrm{I})$ from the surface of adsorbent into the micropores.

Influences of $\mathrm{pH}$ and ionic strength on $\mathrm{TI}(\mathrm{I})$ adsorption. The solution $\mathrm{pH}$ affects not only the species of metal ions but also the surface functional group on the adsorbents for metal ions capturing ${ }^{49}$. Figure 6 demonstrates the influences of solution $\mathrm{pH}$ and ionic strength on $\mathrm{Tl}(\mathrm{I})$ adsorption. Evidently, $\mathrm{Tl}(\mathrm{I})$ adsorption on the $\mathrm{TiO}_{2}{ }^{\mathrm{I}}$ and $\mathrm{TiO}_{2}{ }^{\mathrm{II}}$ is strongly affected by the solution $\mathrm{pH}$ value, increasing gradually with its increase $(2.0-9.0)$. And the optimal adsorption occurs under high alkaline circumstances. A similar trend was observed for the $\mathrm{Tl}(\mathrm{I})$ adsorption on titanium peroxide ${ }^{29}$ and titanium iron magnetic adsorbent ${ }^{43}$. In the tested $\mathrm{pH}$ range from 2.0 to 9.0, positively-charged $\mathrm{Tl}^{+}$is the dominant species for $\mathrm{Tl}(\mathrm{I})$. Under acidic conditions, the surface of $\mathrm{TiO}_{2}$ was favorably protonated and consequently positively charged, which resulted in strong electrostatic repulsion between $\mathrm{Tl}^{+}$and the positively-charged surface and depression of $\mathrm{Tl}^{+}$sorption. With the increase in solution $\mathrm{pH}$ 

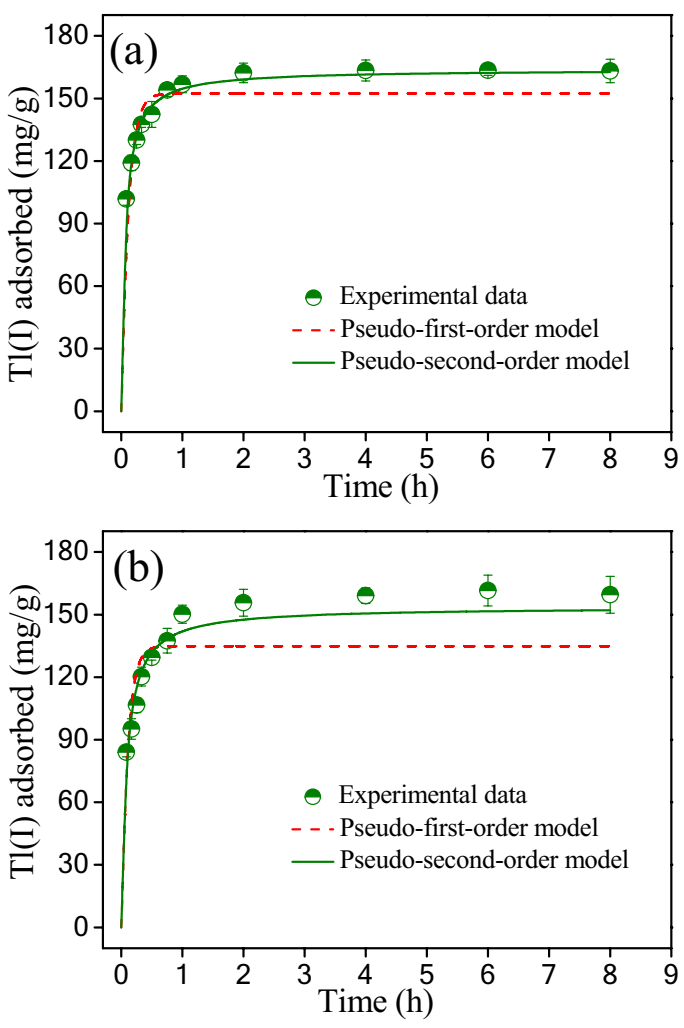

Figure 5. Kinetics of $\mathrm{Tl}(\mathrm{I})$ adsorption on $\mathrm{TiO}_{2}{ }^{\mathrm{I}}(\mathbf{a})$ and $\mathrm{TiO}_{2}{ }^{\mathrm{II}}(\mathbf{b})$. Experiment conditions: Initial $\mathrm{Tl}(\mathrm{I})$ concentration $=34.5 \mathrm{mg} / \mathrm{L}$; adsorbent dosage $=0.2 \mathrm{~g} / \mathrm{L} ; \mathrm{pH}=7.0 \pm 0.1$ and $\mathrm{T}=25 \pm 1{ }^{\circ} \mathrm{C}$.

\begin{tabular}{|c|c|c|c|c|c|c|}
\hline \multirow[b]{2}{*}{ Adsorbent } & \multicolumn{3}{|c|}{ Pseudo first order model } & \multicolumn{3}{|c|}{ Pseudo second order model } \\
\hline & $q_{\mathrm{e}}\left(\mathrm{mg} \mathrm{g}^{-1}\right)$ & $k_{1}\left(\mathrm{~h}^{-1}\right)$ & $R^{2}$ & $q_{\mathrm{e}}\left(\mathrm{mg} \mathrm{g}^{-1}\right)$ & $K_{2}\left(\mathrm{~g} \mathrm{mg}^{-1} \mathrm{~h}^{-1}\right)$ & $R^{2}$ \\
\hline $\mathrm{TiO}_{2}^{\mathrm{I}}$ & 152.5 & 8.93 & 0.910 & 163.9 & 0.102 & 0.995 \\
\hline $\mathrm{TiO}_{2}{ }^{\mathrm{II}}$ & 134.8 & 9.93 & 0.991 & 153.6 & 0.079 & 0.998 \\
\hline
\end{tabular}

Table 3. Kinetic parameters for $\mathrm{Tl}(\mathrm{I})$ adsorption on the $\mathrm{TiO}_{2}{ }^{\mathrm{I}}$ and $\mathrm{TiO}_{2}{ }^{\mathrm{II}}$ fitted with the pseudo first order and pseudo second order models.

value, the $\mathrm{TiO}_{2}$ surface became less positively-charged and turned to be negatively-charged, which was beneficial for the sorption of $\mathrm{Tl}^{+}$. Thus, the uptake of $\mathrm{Tl}^{+}$increased.

As can be seen in Fig. 6, the change in ionic strength (from 0.001 to $0.1 \mathrm{mM}$ ) did not greatly affect the adsorption of $\mathrm{Tl}(\mathrm{I})$ on both $\mathrm{TiO}_{2}{ }^{\mathrm{I}}$ and $\mathrm{TiO}_{2}{ }^{\mathrm{II}}$. Adsorption of ions by formation of outer-sphere complexes is very sensitive to the ionic strength change and always decreases with an increase in ionic strength, since the background electrolyte ions can also form this kind of complex via electrostatic force. On the contrary, adsorption by formation of inner-sphere complexes is insensitive to the variation of ionic strength ${ }^{50}$. Thus, it could be reasonably concluded that the $\mathrm{Tl}(\mathrm{I})$ was specifically adsorbed on the surface of $\mathrm{TiO}_{2}$ by formation of inner-sphere complexes.

Influence of coexisting cations. Cations such as $\mathrm{Ca}^{2+}, \mathrm{Mg}^{2+}$ and $\mathrm{K}^{+}$often exist in the surface water and groundwater ${ }^{51,52}$. Moreover, heavy metal ions such as $\mathrm{Zn}^{2+}, \mathrm{Ni}^{2+}$ and $\mathrm{Cd}^{2+}$ co-occur frequently with $\mathrm{Tl}^{+}$in the mining and industrial wastewaters. These present cations might compete for the adsorptive sites on the surface of $\mathrm{TiO}_{2}{ }^{\mathrm{I}}$ or $\mathrm{TiO}_{2}{ }^{\mathrm{II}}$ with $\mathrm{Tl}^{+}$. Therefore, the influence of these cations on $\mathrm{Tl}^{+}$adsorption was evaluated by batch tests at $\mathrm{pH} 4.5 \pm 0.1$.

Figure 7 shows the experimental results. Interestingly, the coexisting $\mathrm{K}^{+}, \mathrm{Ca}^{2+}, \mathrm{Mg}^{2+}, \mathrm{Zn}^{2+}$ and $\mathrm{Ni}^{2+}$ do not greatly affect the $\mathrm{Tl}^{+}$adsorption and no great decrease is observed even though the concentration of present cations is as high as $10 \mathrm{mM}$. Awual et al. also found that the present $\mathrm{K}^{+}$did not greatly prevent the adsorption of $\mathrm{Cs}^{+}$(similar to $\mathrm{Tl}^{+}$in chemical properties) by crown ether based conjugate material ${ }^{53}$. It is noteworthy that the coexisting $\mathrm{Cd}^{2+}$ inhibits $\mathrm{Tl}^{+}$adsorption. For the $\mathrm{TiO}_{2}{ }^{\mathrm{I}}$, this negative effect is slight and the $\mathrm{Tl}^{+}$adsorption capacity still remains over $90 \%$ when the concentration of $\mathrm{Cd}^{2+}$ reaches up to $10 \mathrm{mM}$, being 100 times higher than that of initial $\mathrm{Tl}^{+}$. However, for the $\mathrm{TiO}_{2}{ }^{\mathrm{II}}$, the negative influence is relatively remarkable and $\mathrm{T}(\mathrm{I})$ adsorption decreases 

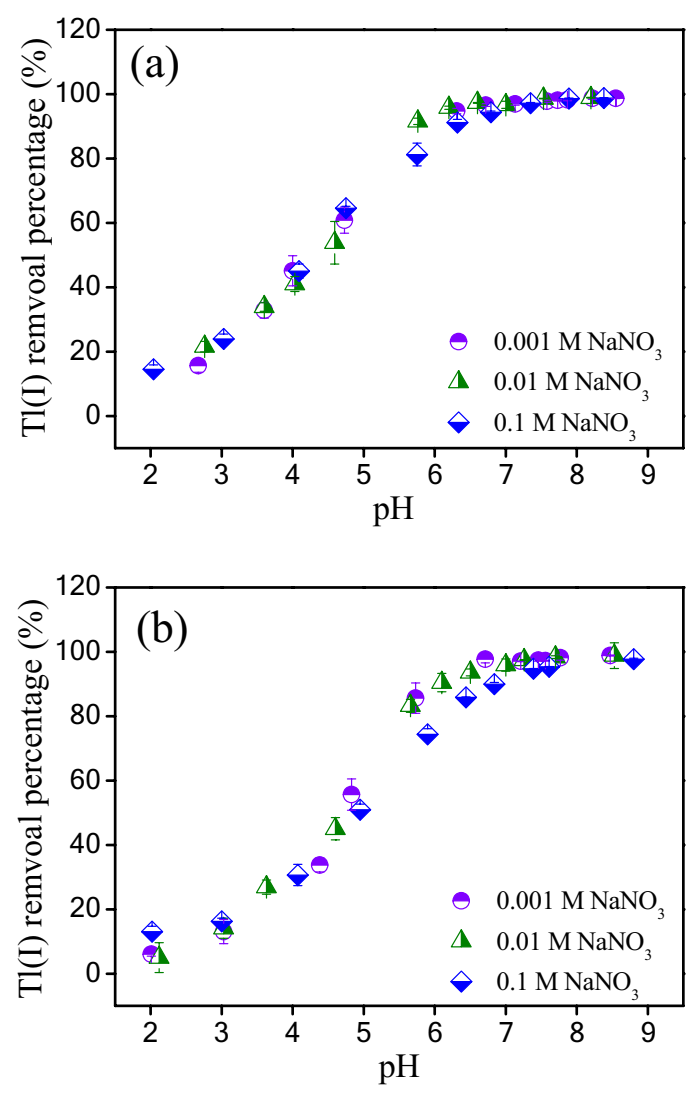

Figure 6. Effects of solution $\mathrm{pH}$ and ionic strength on $\mathrm{Tl}(\mathrm{I})$ adsorption by $\mathrm{TiO}_{2}{ }^{\mathrm{I}}(\mathbf{a})$ and $\mathrm{TiO}_{2}{ }^{\mathrm{II}}(\mathbf{b})$. Experimental conditions: Initial $\mathrm{Tl}(\mathrm{I})$ concentration: $30 \mathrm{mg} / \mathrm{L}$; adsorbent dosage: $0.2 \mathrm{~g} / \mathrm{L} ; \mathrm{T}: 25 \pm 1{ }^{\circ} \mathrm{C}$.

by about $29 \%$ as the concentration of $\mathrm{Cd}^{2+}$ increases from 0 to $10 \mathrm{mM}$. Relatively, both $\mathrm{TiO}_{2}{ }^{\mathrm{I}}$ and $\mathrm{TiO}_{2}{ }^{\mathrm{II}}$ has high selectivity towards $\mathrm{Tl}(\mathrm{I})$ in the presence of multiple cations.

From above, we can see that the adsorption behaviors of $\mathrm{Tl}(\mathrm{I})$ on $\mathrm{TiO}_{2}{ }^{\mathrm{I}}$ and $\mathrm{TiO}_{2}{ }^{\mathrm{II}}$ are very similar. Therefore, we only studied the applicability, regeneration and mechanism of $\mathrm{Tl}(\mathrm{I})$ removal by the $\mathrm{TiO}_{2}{ }^{\mathrm{I}}$ in the following sections.

$\mathrm{TI}(\mathrm{I})$ removal from real surface water and wastewater. To evaluate the applicability of the $\mathrm{TiO}_{2}{ }^{\mathrm{I}}$, kinetics of Tl(I) removal from the surface water (spiked Pearl River water) and mining wastewater were respectively investigated by batch tests. The results are shown in Fig. 8a,b, respectively. For the Pearl River water, when the dosage of $\mathrm{TiO}_{2}^{\mathrm{I}}$ was $20 \mathrm{mg} / \mathrm{L}$, the concentration of residual $\mathrm{Tl}(\mathrm{I})$ in the effluent was lowered to less $2 \mu \mathrm{g} / \mathrm{L}$ within $240 \mathrm{~min}$ (Fig. 8a). $\mathrm{Tl}(\mathrm{I})$ removal became more rapid as the dosage of $\mathrm{TiO}_{2}{ }^{\mathrm{I}}$ increased. When the dosage was $40 \mathrm{mg} / \mathrm{L}$, the residual Tl(I) reduced to less $2 \mu \mathrm{g} / \mathrm{L}$ within $120 \mathrm{~min}$ and below $1 \mu \mathrm{g} / \mathrm{L}$ at $360 \mathrm{~min}$. For mining wastewater, when the dosage was $25 \mathrm{mg} / \mathrm{L}$, the Tl concentration in the effluent was below $2 \mu \mathrm{g} / \mathrm{L}$ after treatment for $210 \mathrm{~min}$. As the dosage increased to $50 \mathrm{mg} / \mathrm{L}$, the residual $\mathrm{Tl}$ decreased rapidly from 4.7 to less $2 \mu \mathrm{g} / \mathrm{L}$ within 30 min (Fig. 8b). These results suggest that the $\mathrm{TiO}_{2}{ }^{\mathrm{I}}$ is highly efficient for $\mathrm{Tl}(\mathrm{I})$ removal from the river water and real mining wastewater and has good applicability.

Regeneration and reusability of $\mathrm{TiO}_{2}{ }^{1}$. The regeneration and reusability of adsorbent is an important factor affecting its use in real water treatment ${ }^{54}$. In order to assess the reusability of $\mathrm{TiO}_{2}{ }^{\mathrm{I}}$, the $\mathrm{Tl}(\mathrm{I})$ desorption from spent adsorbent was investigated using $0.1 \mathrm{M} \mathrm{HCl}$ solution as desorbing agent and then the regenerated adsorbent was used in another adsorption-desorption cycle. Figure 9 illustrates the results of five consecutive adsorption/regeneration cycles. The cycle 0 is corresponding to the $\mathrm{Tl}(\mathrm{I})$ adsorption by the fresh $\mathrm{TiO}_{2}^{\mathrm{I}}$. As can be seen, the adsorption percentage of $\mathrm{Tl}(\mathrm{I})$ decreases with an increase in the number of cycles. After the first regeneration, the adsorption percentage of $\mathrm{Tl}(\mathrm{I})$ by the regenerated adsorbent reduces from 98.7 to $79.3 \%$. This value is further lowered to $60.1 \%$ after the third regeneration and $45.3 \%$ after the fifth regeneration. Apparently, the reusability of $\mathrm{TiO}_{2}{ }^{\mathrm{I}}$ is moderate, which may be ascribed to the relatively strong affinity between $\mathrm{Tl}(\mathrm{I})$ and the $\mathrm{TiO}_{2}{ }^{\mathrm{I}}$. These results suggest that the $\mathrm{TiO}_{2}{ }^{\mathrm{I}}$ could be regenerated but the times of reuse are limited.

XPS analysis before and after $\mathrm{TI}(\mathrm{I})$ adsorption. In order to reveal the mechanism of $\mathrm{Tl}(\mathrm{I})$ adsorption by the $\mathrm{TiO}_{2}{ }^{\mathrm{I}}$, XPS spectra of the $\mathrm{TiO}_{2}{ }^{\mathrm{I}}$ before and after $\mathrm{Tl}(\mathrm{I})$ uptake were determined and analyzed. Figure 10a 

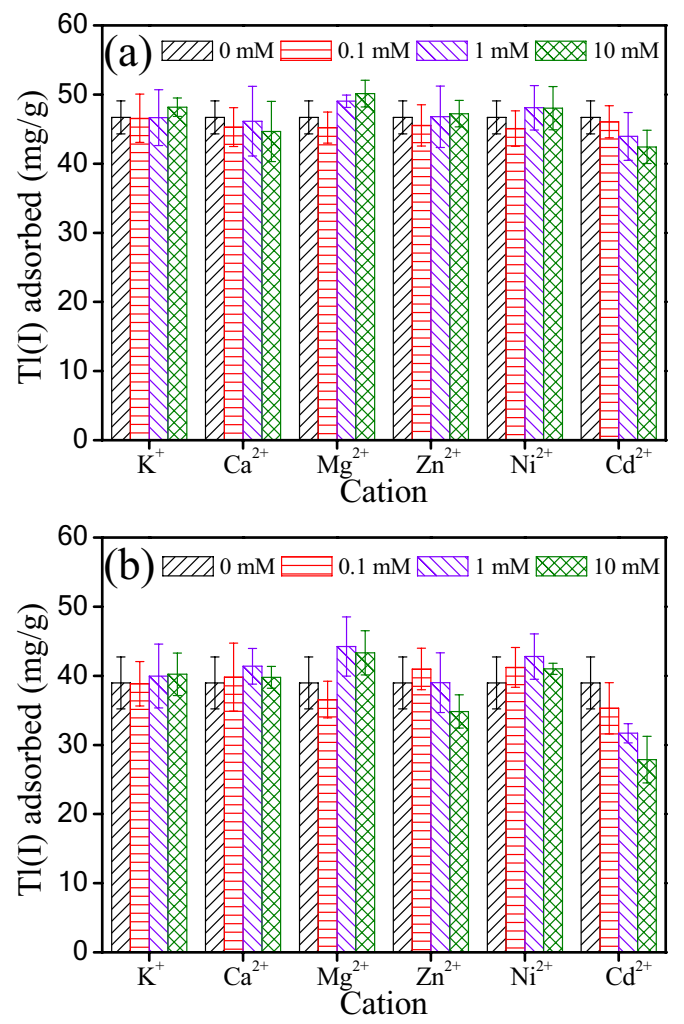

Figure 7. Influence of coexisting cations on $\mathrm{Tl}(\mathrm{I})$ adsorption by the $\mathrm{TiO}_{2}{ }^{\mathrm{I}}(\mathbf{a})$ and $\mathrm{TiO}_{2}{ }^{\mathrm{II}}(\mathbf{b})$. Experiment conditions: $\mathrm{Tl}(\mathrm{I})$ concentration $=18.5 \mathrm{mg} / \mathrm{L} ;$ adsorbent dosage $=0.2 \mathrm{~g} / \mathrm{L} ; \mathrm{pH} 4.5 \pm 0.1$ and $\mathrm{T}=25 \pm 1^{\circ} \mathrm{C}$.
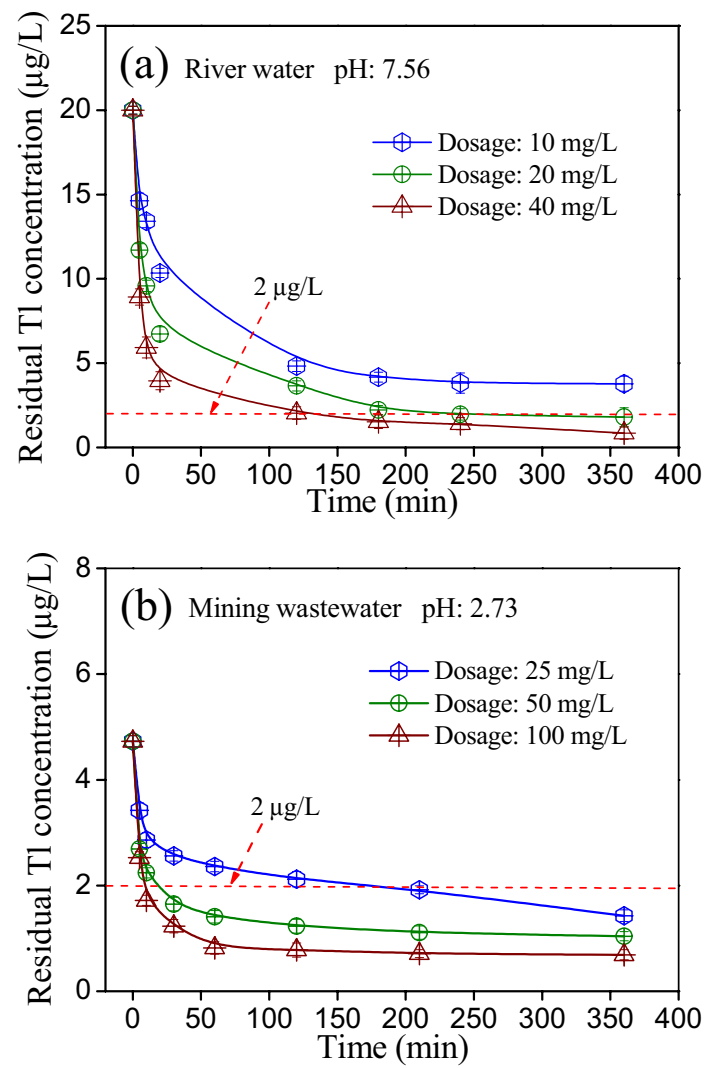

Figure 8. Kinetics of $\mathrm{Tl}(\mathrm{I})$ removal by $\mathrm{TiO}_{2}{ }^{\mathrm{I}}$ from the (a) spiked Pearl River water and (b) mining wastewater. 


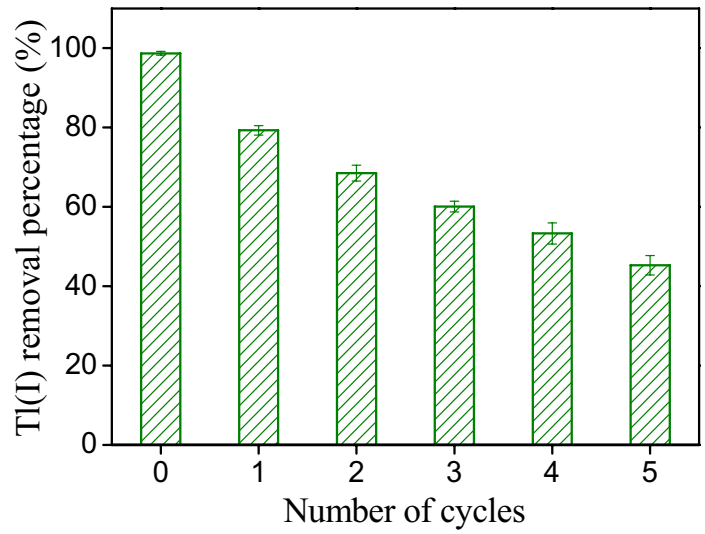

Figure 9. Variation of $\mathrm{Tl}(\mathrm{I})$ adsorption by the $\mathrm{TiO}_{2}{ }^{\mathrm{I}}$ as a function of regeneration cycle.
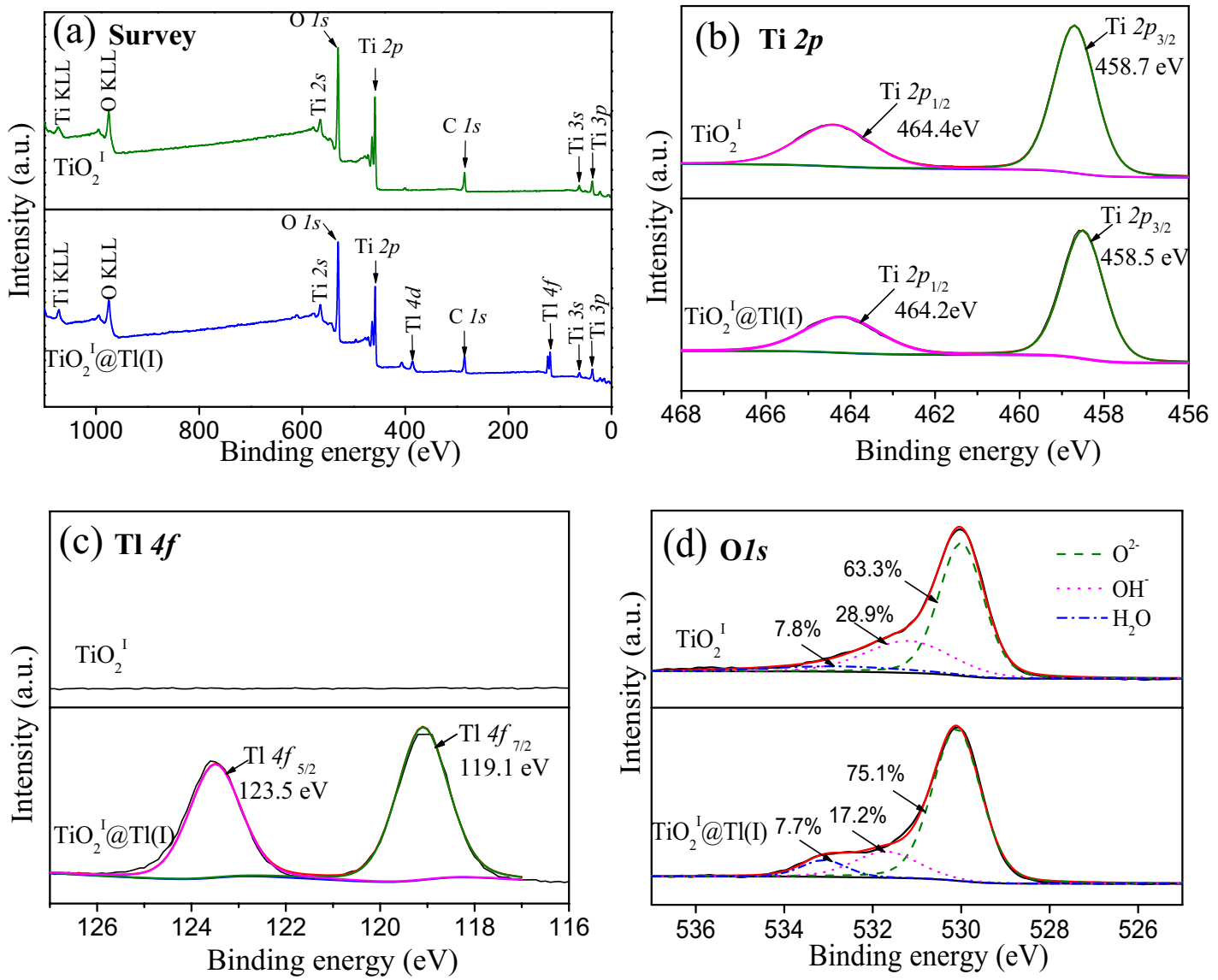

Figure 10. XPS spectra of $\mathrm{TiO}_{2}^{\mathrm{I}}$ before and after $\mathrm{Tl}(\mathrm{I})$ adsorption. (a) Survey spectra, (b) high-resolution $\mathrm{Ti} 2 P$ spectra, (c) high-resolution Tl $4 f$ spectra, (d) high-resolution $\mathrm{O} 1 s$ spectra.

presents the survey spectra of the original and $\mathrm{Tl}(\mathrm{I})$-sorbed $\mathrm{TiO}_{2}{ }^{\mathrm{I}}$. Characteristic Ti peaks including $\mathrm{Ti} 2 p$, Ti $2 s$, $\mathrm{Ti} 3 p$, Ti $3 s$ and Ti KLL along with $\mathrm{O}$ peaks are observed in the spectra of the original $\mathrm{TiO}_{2}{ }^{\mathrm{I}}$. After reaction with $\mathrm{Tl}(\mathrm{I})$, two characteristic $\mathrm{Tl}$ peaks of $\mathrm{Tl} 4 f$ and $\mathrm{Tl} 4 d$ appear, suggesting that $\mathrm{Tl}(\mathrm{I})$ was adsorbed on the surface of $\mathrm{TiO}_{2}{ }^{\mathrm{I}}$. High resolution XPS spectra of $\mathrm{Ti} 2 p$, Tl $4 f$ and $\mathrm{O} 1 \mathrm{~s}$ of the pristine and $\mathrm{Tl}(\mathrm{I})$-loaded $\mathrm{TiO}_{2}{ }^{\mathrm{I}}$ are illustrated in Fig. 10b-d, respectively. The doublet peaks of Ti $2 p_{3 / 2}$ and $\mathrm{Ti} 2 p_{1 / 2}$ are located at $458.7 \mathrm{eV}$ and $464.4 \mathrm{eV}$, respectively, indicating that the oxidation state of $\mathrm{Ti}$ in the $\mathrm{TiO}_{2}{ }^{\mathrm{I}}$ is $+4^{29,55,56}$. These two peaks exhibit a slight shift $(0.2 \mathrm{eV})$ to lower binding energy after $\mathrm{Tl}(\mathrm{I})$ sorption, which might be ascribed to the presence of strong interaction between $\mathrm{TiO}_{2}{ }^{\mathrm{I}}$ and $\mathrm{Tl}(\mathrm{I})$. The two peaks of $\mathrm{Tl} 4 f_{7 / 2}$ and $\mathrm{Tl} 4 f_{5 / 2}$ are located at $119.1 \mathrm{eV}$ and $123.5 \mathrm{eV}$, respectively, indicating that the oxidation state of $\mathrm{Tl}$ sorbed is $+1^{23}$. Obviously, no $\mathrm{Tl}(\mathrm{I})$ oxidation occurs during its adsorption by $\mathrm{TiO}_{2}{ }^{1}$. The $\mathrm{O} 1 s$ spectra can be divided into three peaks situated at 530.2, 531.7 and 533.1, cor- 


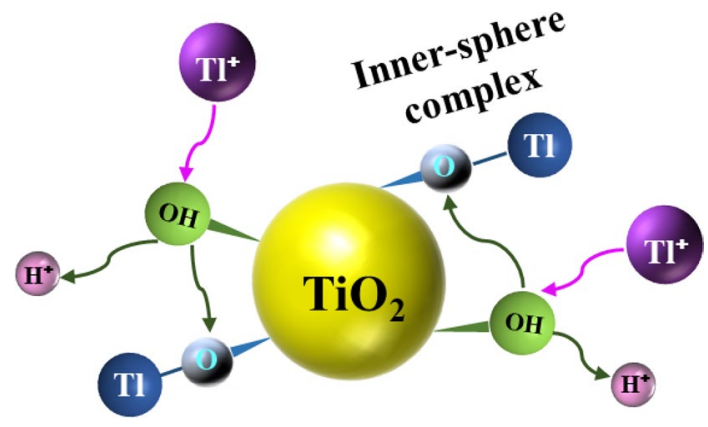

Figure 11. The proposed mechanism of $\mathrm{Tl}(\mathrm{I})$ adsorption on $\mathrm{TiO}_{2}$.

responding to lattice oxygen $\left(\mathrm{O}^{2-}\right)$, surface hydroxyl $(-\mathrm{OH})$, and sorbed water $\left(\mathrm{H}_{2} \mathrm{O}\right)$, respectively. For the virgin $\mathrm{TiO}_{2}{ }^{\mathrm{I}}$, the contents of $\mathrm{O}^{2-},-\mathrm{OH}$ and $\mathrm{H}_{2} \mathrm{O}$ are $63.3,28.9$ and $7.8 \%$, respectively. After $\mathrm{Tl}(\mathrm{I})$ sorption, the content of $\mathrm{H}_{2} \mathrm{O}$ showed no significant change, while the content of $-\mathrm{OH}$ species decreased obviously from 28.9 to $17.2 \%$ and correspondingly, the content of $\mathrm{O}^{2-}$ increased from 63.3 to $75.1 \%$. Obviously, the $\mathrm{H}^{+}$in $-\mathrm{OH}$ group was replaced by the $\mathrm{Tl}(\mathrm{I})$ species during its removal.

From the above-mentioned analysis, a possible mechanism of $\mathrm{Tl}(\mathrm{I})$ removal by the $\mathrm{TiO}_{2}{ }^{\mathrm{I}}$ was established and the schematic diagram was illustrated in Fig. 11. Firstly, the $\mathrm{Tl}^{+}$was transported to the surface of $\mathrm{TiO}_{2}{ }^{\mathrm{I}}$ from bulk solution. Afterwards, the $\mathrm{Tl}^{+}$replaced the $\mathrm{H}^{+}$in -OH group on the surface of $\mathrm{TiO}_{2}{ }^{\mathrm{I}}$ and an inner-sphere surface complex (Ti-O-Tl) was formed. Meanwhile, the $\mathrm{H}^{+}$was released and entered into the bulk solution.

\section{Conclusions}

Hydrous titanium dioxide was facilely synthesized by precipitation method and forced hydrolysis method, respectively. The $\mathrm{TiO}_{2}$ prepared at room temperature is amorphous and effective for $\mathrm{Tl}(\mathrm{I})$ adsorption, exhibiting high maximal adsorption capacities of $230.3-302.6 \mathrm{mg} / \mathrm{g}$ under neutral $\mathrm{pH}$ conditions. These values outperform the majority of reported adsorbents. The $\mathrm{Tl}(\mathrm{I})$ adsorption is strongly $\mathrm{pH}$-dependent, increasing with an increase in solution $\mathrm{pH}$ value. The $\mathrm{TiO}_{2}$ has high selectivity for $\mathrm{T}(\mathrm{I})$ adsorption and it can be used repeatedly, though the times of reuse are limited. The mechanism of $\mathrm{Tl}(\mathrm{I})$ removal is that the $\mathrm{H}^{+}$in $-\mathrm{OH}$ on the surface of $\mathrm{TiO}_{2}$ was replaced by $\mathrm{Tl}^{+}$and inner-sphere surface complex was formed. The synthesized $\mathrm{TiO}_{2}$ has the potential to be used as an alternative adsorbent to remove $\mathrm{Tl}(\mathrm{I})$ from water, owing to its high efficiency, high stability, affordable cost, facile synthesis and environmental friendliness.

Received: 9 August 2021; Accepted: 8 December 2021

Published online: 07 January 2022

\section{References}

1. Peter, A. L. J. \& Viraraghavan, T. Thallium: a review of public health and environmental concerns. Environ. Int. 31, 493-501 (2005).

2. Xiao, T. F., Yang, F., Li, S. H., Zheng, B. S. \& Ning, Z. P. Thallium pollution in China: A geo-environmental perspective. Sci. Total Environ. 421-422, 51-58 (2012).

3. Xu, H. Y. et al. Removal of thallium in water/wastewater: A review. Water Res. 165, 114981 (2019).

4. Liu, J. et al. Thallium pollution in China and removal technologies for waters: A review. Environ. Int. 126, 771-790 (2019).

5. Li, H. S. et al. Highly efficient removal of thallium(I) from wastewater via hypochlorite catalytic oxidation coupled with adsorption by hydrochar coated nickel ferrite composite. J. Hazard. Mater. 388, 122016 (2020).

6. Zhao, Z. et al. Adsorptive removal of trace thallium(I) from wastewater: A review and new perspectives. J. Hazard. Mater. 393, 122378 (2020).

7. Liu, J. et al. Highly efficient removal of thallium in wastewater by $\mathrm{MnFe}_{2} \mathrm{O}_{4}$-biochar composite. J. Hazard. Mater. 401, 123311 (2021).

8. Davies, M., Figueroa, L., Wildeman, T. \& Bucknam, C. The oxidative precipitation of thallium at alkaline pH for treatment of mining influenced water. Mine Water Environ. 35, 77-85 (2016).

9. Liu, Y. L. et al. Highly efficient removal of trace thallium from contaminated source waters with ferrate: Role of in situ formed ferric nanoparticle. Water Res. 124, 149-157 (2017).

10. Liu, Y. L. et al. Treatment of trace thallium in contaminated source waters by ferrate peroxidation and poly aluminium chloride coagulation. Sep. Purif. Technol. 227, 115663 (2019).

11. Sinyakova, M. A., Semenova, E. A. \& Gamuletskaya, O. A. Ion exchange of copper(II), lanthanum(III), thallium(I), and mercury(II) on the "polysurmin" substance. Russ. J. Gen. Chem. 84, 2516-2520 (2014).

12. Li, H. S. et al. Simultaneous removal of thallium and chloride from a highly saline industrial wastewater using modified anion exchange resins. J. Hazard Mater. 333(Suppl C), 179-185 (2017).

13. Zhang, X. Y., Yin, G. Y. \& Hu, Z. G. Extraction and separation of gallium, indium and thallium with several carboxylic acids from chloride media. Talanta 59, 905-912 (2003).

14. Hassanien, M. M., Kenawy, I. M., Mostafa, M. R. \& El-Dellay, H. Extraction of gallium, indium and thallium from aquatic media using amino silica gel modified by gallic acid. Microchim. Acta 172, 137-145 (2011).

15. Hanafi, A. Adsorption of cesium, thallium, strontium and cobalt radionuclides using activated carbon. Asian J. Chem. 1, 292-300 (2010).

16. Pu, Y. B. et al. Adsorption and desorption of thallium(I) on multiwalled carbon nanotubes. Chem. Eng. J. 219, 403-410 (2013).

17. Deng, H. M. et al. Adsorption of $\mathrm{Tl}(\mathrm{I})$ on Na-montmorillonite and kaolinite from aqueous solutions. Environ. Earth Sci. 75, 752 (2016). 
18. Wick, S., Baeyens, B., Fernandes, M. M. \& Voegelin, A. Thallium adsorption onto illite. Environ. Sci. Technol. 52, 571-580 (2018).

19. Birungi, Z. S. \& Chirwa, E. M. N. The adsorption potential and recovery of thallium using green micro-algae from eutrophic water sources. J. Hazard. Mater. 299, 67-77 (2015).

20. Rauws, A. \& Canton, J. Adsorption of thallium ions by Prussian Blue. Bull. Environ. Contam. Toxicol. 15, 335-336 (1976).

21. Sangvanich, T. et al. Selective capture of cesium and thallium from natural waters and simulated wastes with copper ferrocyanide functionalized mesoporous silica. J. Hazard. Mater. 182, 225-231 (2010).

22. Vincent, T. et al. Thallium(I) sorption using Prussian blue immobilized in alginate capsules. Carbohyd. Polym. 99, 517-526 (2014).

23. Wan, S. L. et al. Selective capture of thallium(I) ion from aqueous solutions by amorphous hydrous manganese dioxide. Chem. Eng. J. 239, 200-206 (2014).

24. Pan, B. C. et al. Recyclable polymer-based nano-hydrous manganese dioxide for highly efficient $\mathrm{Tl}(\mathrm{I})$ removal from water. Sci. China Chem. 57, 763-771 (2014)

25. Huangfu, X. L. et al. Adsorption and oxidation of thallium(I) by a nanosized manganese dioxide. Water Air Soil Pollut. 226, 2272 (2015).

26. Li, K. K. et al. Synthesis of manganese dioxide with different morphologies for thallium removal from wastewater. J. Environ. Manage. 251, 109563 (2019).

27. Wick, S., Pena, J. \& Voegelin, A. Thallium sorption onto manganese oxides. Environ. Sci. Technol. 53, 13168-13178 (2019).

28. Liu, W., Zhang, P., Borthwick, A. G. L., Chen, H. \& Ni, J. R. Adsorption mechanisms of thallium(I) and thallium(III) by titanate nanotubes: Ion-exchange and co-precipitation. J. Colloid Interface Sci. 423, 67-75 (2014).

29. Zhang, G. S., Fan, F., Li, X. P., Qi, J. Y. \& Chen, Y. H. Superior adsorption of thallium(I) on titanium peroxide: Performance and mechanism. Chem. Eng. J. 331, 471-479 (2018).

30. Wang, N. N. et al. Removal of thallium(I) from aqueous solutions using titanate nanomaterials: The performance and the influence of morphology. Sci. Total Environ. 717, 137090 (2020).

31. Guan, X. H. et al. Application of titanium dioxide in arsenic removal from water: A review. J. Hazard. Mater. 215, 1-16 (2012).

32. Liu, W. et al. Adsorption of $\mathrm{Pb}^{2+}, \mathrm{Cd}^{2+}, \mathrm{Cu}^{2+}$ and $\mathrm{Cr}^{3+}$ onto titanate nanotubes: Competition and effect of inorganic ions. Sci. Total Environ. 456, 171-180 (2013).

33. Mahdavi, S., Jalali, M. \& Afkhami, A. Heavy metals removal from aqueous solutions using $\mathrm{TiO}_{2}, \mathrm{MgO}$, and $\mathrm{Al}_{2} \mathrm{O}_{3}$ nanoparticles. Chem. Eng. Commun. 200, 448-470 (2013).

34. Tsydenov, D. E., Shutilov, A. A., Zenkovets, G. A. \& Vorontsov, A. V. Hydrous $\mathrm{TiO}_{2}$ materials and their application for sorption of inorganic ions. Chem. Eng. J. 251, 131-137 (2014).

35. Borai, E. H., Breky, M. M. E., Sayed, M. S. \& Abo-Aly, M. M. Synthesis, characterization and application of titanium oxide nanocomposites for removal of radioactive cesium, cobalt and europium ions. J. Colloid Interface Sci. 450, 17-25 (2015).

36. Kajitvichyanukul, P., Chenthamarakshan, C. R., Rajeshwar, K. \& Qasim, S. R. Photocatalytic reactivity of thallium(I) species in aqueous suspensions of titania. J. Electroanal. Chem. 519, 25-32 (2002).

37. Asadpour, S., Chamsaz, M., Entezari, M. H., Haron, M. J. \& Ghows, N. On-line preconcentration of ultra-trace thallium(I) in water samples with titanium dioxide nanoparticles and determination by graphite furnace atomic absorption spectrometry. Arab. J. Chem. 9, S1833-S1839 (2016).

38. Zhang, W. L. et al. Adsorption of thallium(I) on rutile nano-titanium dioxide and environmental implications. PeerJ 7, e6820 (2019).

39. Wang, X. J. et al. Construction of amorphous $\mathrm{TiO}_{2} / \mathrm{BiOBr}$ heterojunctions via facets coupling for enhanced photocatalytic activity. J. Hazard. Mater. 292, 126-136 (2015).

40. Chen, M. Q. et al. FeOOH-loaded $\mathrm{MnO}_{2}$ nano-composite: An efficient emergency material for thallium pollution incident. J. Environ. Manage. 192, 31-38 (2017).

41. Li, H. S. et al. Removal of thallium from aqueous solutions using Fe-Mn binary oxides. J. Hazard. Mater. 338, 296-305 (2017).

42. Li, H. S. et al. Efficient removal of thallium(I) from wastewater using flower-like manganese dioxide coated magnetic pyrite cinder. Chem. Eng. J. 353, 867-877 (2018).

43. Tang, J. L. et al. Study on adsorption properties and mechanism of thallium onto titanium iron magnetic adsorbent. Sci. Total Environ. 694, 133625 (2019)

44. Li, H. S. et al. Biochar derived from watermelon rinds as regenerable adsorbent for efficient removal of thallium(I) from wastewater. Process Saf. Environ. 127, 257-266 (2019).

45. López, Y. C., Ortega, G. A., Martínez, M. A. \& Reguera, E. Magnetic Prussian Blue derivative like absorbent cages for an efficient thallium removal. J. Clean. Prod. 283, 124587 (2021).

46. Badruzzaman, M., Westerhoff, P. \& Knappe, D. R. U. Intraparticle diffusion and adsorption of arsenate onto granular ferric hydroxide (GFH). Water Res. 38, 4002-4012 (2004).

47. Pan, S. Y., Syu, W. J., Chang, T. K. \& Lee, C. H. A multiple model approach for evaluating the performance of time-lapse capsules in trapping heavy metals from water bodies. RSC Adv. 10, 16490-16501 (2020).

48. D’Arcy, M., Weiss, D., Bluck, M. \& Vilar, R. Adsorption kinetics, capacity and mechanism of arsenate and phosphate on a bifunctional $\mathrm{TiO}_{2}-\mathrm{Fe}_{2} \mathrm{O}_{3}$ bi-composite. J. Colloid Interf. Sci. 364, 205-212 (2011).

49. Kubra, K. T. et al. Utilizing an alternative composite material for effective copper(II) ion capturing from wastewater. J. Mol. Liq. 336, 116325 (2021).

50. McBride, M. B. A critique of diffuse double layer models applied to colloid and surface chemistry. Clays Clay Miner. 45, 598-608 (1997).

51. Awual, M. R. A novel facial composite adsorbent for enhanced copper(II) detection and removal from wastewater. Chem. Eng. J. 266, 368-375 (2015).

52. Awual, M. R., Hasan, M. M., Khaleque, M. A. \& Sheikh, M. C. Treatment of copper(II) containing wastewater by a newly developed ligand based facial conjugate materials. Chem. Eng. J. 288, 368-376 (2016).

53. Awual, M. R., Yaita, T., Kobayashi, T., Shiwaku, H. \& Suzuki, S. Improving cesium removal to clean-up the contaminated water using modified conjugate material. J. Environ. Chem. Eng. 8, 103684 (2020).

54. Awual, M. R. et al. Ligand based sustainable composite material for sensitive nickel(II) capturing in aqueous media. J. Environ. Chem. Eng. 8, 103591 (2020).

55. Xiong, L. B., Li, J. L., Yang, B. \& Yu, Y. Ti ${ }^{3+}$ in the surface of titanium dioxide: Generation, properties and photocatalytic application. J. Nanomater. 2012, 1-13 (2012).

56. Xin, X. Y., Xu, T., Wang, L. \& Wang, C. Y. Ti ${ }^{3+}$-self doped brookite $\mathrm{TiO}_{2}$ single-crystalline nanosheets with high solar absorption and excellent photocatalytic $\mathrm{CO}_{2}$ reduction. Sci. Rep. 6, 23684 (2016).

\section{Acknowledgements}

The authors acknowledge the financial support from National Natural Science Foundation of China (No. 51678562) and the Research Fund Program of Guangdong Key Laboratory of Radioactive and Rare Resource Utilization (2018B030322009). 


\section{Author contributions}

G.Z.: Conceptualization; Writing-Original draft preparation. J.L.: Investigation; Validation. H.C.: Investigation; Formal analysis. S.H.: Investigation. H.L.: Data Curation; Formal analysis. Z.W.: Investigation. Y.X.: Investigation. X.L.: Conceptualization, Writing-Reviewing and Editing.

\section{Competing interests}

The authors declare no competing interests.

\section{Additional information}

Supplementary Information The online version contains supplementary material available at https://doi.org/ 10.1038/s41598-021-03985-3.

Correspondence and requests for materials should be addressed to G.Z. or X.L.

Reprints and permissions information is available at www.nature.com/reprints.

Publisher's note Springer Nature remains neutral with regard to jurisdictional claims in published maps and institutional affiliations.

Open Access This article is licensed under a Creative Commons Attribution 4.0 International License, which permits use, sharing, adaptation, distribution and reproduction in any medium or
format, as long as you give appropriate credit to the original author(s) and the source, provide a link to the Creative Commons licence, and indicate if changes were made. The images or other third party material in this article are included in the article's Creative Commons licence, unless indicated otherwise in a credit line to the material. If material is not included in the article's Creative Commons licence and your intended use is not permitted by statutory regulation or exceeds the permitted use, you will need to obtain permission directly from the copyright holder. To view a copy of this licence, visit http://creativecommons.org/licenses/by/4.0/.

(C) The Author(s) 2022 